\title{
Correction to: Security of facial biometric authentication for attendance system
}

\author{
Vera Wati ${ }^{1} \cdot$ Kusrini Kusrini ${ }^{2}$ (D) Hanif Al Fatta ${ }^{2} \cdot$ Nitika Kapoor $^{3}$ \\ Published online: 3 March 2021 \\ (C) Springer Science+Business Media, LLC, part of Springer Nature 2021
}

\section{Correction to: Multimedia Tools and Applications (2021) https://doi.org/10.1007/s11042-020-10246-4}

The corresponding author in the original publication was incorrect. The original article has been corrected.

Publisher's note Springer Nature remains neutral with regard to jurisdictional claims in published maps and institutional affiliations.

The online version of the original article can be found at https://doi.org/10.1007/s11042-020-10246-4

\author{
Kusrini Kusrini \\ kusrini@amikom.ac.id \\ Vera Wati \\ vera.w@lecture.utp.ac.id \\ Hanif Al Fatta \\ hanif.a@amikom.ac.id \\ Nitika Kapoor \\ nitika.cse@cumail.in
}

1 Universitas Tunas Pembangunan Surakarta, Jl. Balekambang Lor No. 1, Surakarta, Jawa Tengah, Indonesia

2 Universitas AMIKOM Yogyakarta, Jl. Ringroad Utara Condong Catur Depok Sleman, Yogyakarta, Indonesia

3 Chandigarh University, NH-95 Chandigarh-Ludhiana Highway, Mohali, Punjab, India 